\title{
Characterization of the DdrD protein from the extremely radioresistant bacterium Deinococcus radiodurans
}

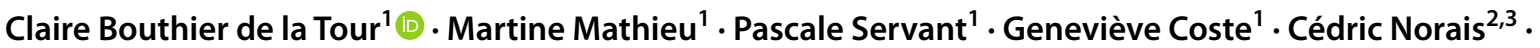 \\ Fabrice Confalonieri ${ }^{1}$
}

Received: 5 January 2021 / Accepted: 16 May 2021 / Published online: 29 May 2021

(c) The Author(s) 2021

\begin{abstract}
Here, we report the in vitro and in vivo characterization of the DdrD protein from the extraordinary stress-resistant bacterium, D. radiodurans. DdrD is one of the most highly induced proteins following cellular irradiation or desiccation. We confirm that DdrD belongs to the Radiation Desiccation Response (RDR) regulon protein family whose expression is regulated by the IrrE/DdrO proteins after DNA damage. We show that DdrD is a DNA binding protein that binds to single-stranded DNA In vitro, but not to duplex DNA unless it has a 5' single-stranded extension. In vivo, we observed no significant effect of the absence of DdrD on the survival of $D$. radiodurans cells after exposure to $\gamma$-rays or UV irradiation in different genetic contexts. However, genome reassembly is affected in a $\Delta d d r D$ mutant when cells recover from irradiation in the absence of nutrients. Thus, DdrD likely contributes to genome reconstitution after irradiation, but only under starvation conditions. Lastly, we show that the absence of the DdrD protein partially restores the frequency of plasmid transformation of a $\Delta d d r B$ mutant, suggesting that DdrD could also be involved in biological processes other than the response to DNA damage.
\end{abstract}

Keywords Deinococcus radiodurans $\cdot \operatorname{DdrD} \cdot$ DNA binding protein $\cdot$ DNA damage response

\section{Introduction}

Communicated by H. Atomi.

Claire Bouthier de la Tour

claire.bouthier@i2bc.paris-saclay.fr

Martine Mathieu

martine.porteron@gmail.com

Pascale Servant

pascale.servant@i2bc.paris-saclay.fr

Geneviève Coste

genevieve.coste@i2bc.paris-saclay.fr

Cédric Norais

cedric.norais@promega.com

Fabrice Confalonieri

fabrice.confalonieri@i2bc.paris-saclay.fr

1 Institute for Integrative Biology of the Cell (I2BC), CEA, CNRS, Université Paris-Saclay, 91198 Gif sur Yvette, France

2 Department of Biochemistry, University of Wisconsin, Madison, WI 53706, USA

3 Present Address: SAT Lyon, Promega France, 24 Chemin des Verrieres, 69260 Charbonnières les Bains, France
Deinococcus radiodurans is well known for its extreme resistance to radiation, desiccation and various DNA-damaging chemicals such as mitomycin $\mathrm{C}$ and hydrogen peroxide. Data from various studies (Ishino and Narumi 2015; Slade and Radman 2011) strongly suggested that the radioresistance of $D$. radiodurans is a combination of multiple strategies, including protection of proteins against oxidation, efficient DNA repair pathways, a condensed nucleoid structure favoring the maintenance of DNA fragment cohesion after irradiation.

Global analysis of $D$. radiodurans genome expression allowed the identification of a series of genes whose expression is induced after irradiation or desiccation (Tanaka et al. 2004). Most of the highly induced genes encode proteins involved in DNA repair (RecA, RuvB, UvrA, UvrB, UvrD), DNA supercoiling (GyrA and GyrB) as well as several deinococcal specific proteins (PprA, DdrA, DdrB, DdrC, DdrD) involved in the response to DNA damage. All these genes contain a 17 bp RDRM (Radiation Desiccation Response Motif) sequence in their promoter region (Makarova et al. 2007), a hallmark of a set of genes identified 
as members of a radiation/desiccation response (RDR) regulon. It was previously shown that the expression of predicted RDR proteins in D. radiodurans like PprA, GyrA, DdrB, and $\mathrm{DdrC}$, is regulated by the couple of IrrE and DdrO proteins after DNA damage (de la Tour et al. 2017; Devigne et al. 2015). DdrO binds to the RDRM sequence and acts as a repressor of the RDR regulon (Blanchard et al. 2017; Wang et al. 2015). After irradiation, IrrE stimulated by an increased availability of zinc ions (Blanchard et al. 2017), is able to cleave the DdrO repressor, then leading to the derepression of the RDR genes.

The PprA, DdrA, DdrB, DdrC, and DdrD proteins are recruited to the nucleoid early after exposure to $\gamma$-irradiation (de la Tour et al. 2011, 2013,2017; Devigne et al. 2013). The PprA, DdrA, DdrB, and DdrC proteins have been well characterized and were proposed to be part of the $D$. radiodurans genome-protection system. They are DNA binding proteins that exhibit various and redundant activities. PprA protein preferentially binds to double-stranded DNA (dsDNA) ends, stimulates in vitro DNA ligase activity (Narumi et al. 2004) and in vivo was found to be involved in chromosome segregation (Devigne et al. 2013, 2016; Kota et al. 2014a, b). DdrB is an SSB-like protein (Norais et al. 2009) that binds to single-stranded DNA (ssDNA) and stimulates annealing of complementary ssDNA. DdrB participates in the early stages of DNA double strand break repair through a single strand annealing (SSA) mechanism when cells are exposed to high levels of irradiation (de la Tour et al. 2011; Xu et al. 2010). DdrA preferentially binds to 3 ' ssDNA ends and protects them from nuclease degradation, suggesting that it contributes to the preservation of genome integrity after irradiation (Harris et al. 2004). More recently, we have shown that DdrC is a DNA binding protein that binds single and double-stranded DNA with a preference for the ssDNA, protects DNA from nuclease attack and exhibits a DNA strand annealing activity (de la Tour et al. 2017). It was suggested that DdrC maintains DNA fragments end to end, thus limiting dispersion and extensive degradation after exposure to high doses of radiation. However, while the properties of PprA, DdrA, DdrB, and DdrC proteins are well documented, little is known about the DdrD protein.

Here, we investigated the in vitro and in vivo properties of the DdrD protein to gain a better understanding of its potential role in irradiated cells. We showed that the expression of DdrD is induced after $\gamma$-irradiation and is under the control of the IrrE/DdrO system. In vitro, the DdrD protein binds to ssDNA and to dsDNA with a single-stranded 5' extension. Although it does not protect DNA from nuclease attack, we showed that its absence alters genome reconstitution after $D$. radiodurans cells were irradiated and recovered in a nutrient-poor environment. We also re-examined the effects in vivo of associated deletions of the $d d r A, d d r B, d d r C$, and $d d r D$ genes on the cellular response to exposure to $\gamma$-rays and to UV irradiation. For this purpose, we constructed all possible double, triple, and quadruple mutants. Analysis of the resulting strains revealed no significant effect of the $d d r D$ deletion, even if this deletion was associated with deletions of $d d r A, d d r B$, and $d d r C$ genes. Finally, we showed that the absence of DdrD partially suppresses the impact of the deletion of the $d d r B$ gene on plasmid transformation suggesting that the DdrD protein, like other Ddr proteins, may be involved in several different biological processes.

\section{Materials and methods}

\section{Bacterial strains, plasmids, and growth conditions}

Bacterial strains and plasmids used in this study are listed in Table 1 . To construct $D$. radiodurans deletion mutants or strains expressing a recombinant tagged protein, the loci of interest were replaced with the appropriate antibiotic resistance cassette or their tagged counterparts, respectively, using the tripartite ligation method (Mennecier et al. 2004). The double mutants were constructed by transformation of a single mutant by the genomic DNA of another single mutant. The same strategy was used for the construction of triple and quadruple mutants. Genomic DNA of D. radiodurans was purified and transformation of D. radiodurans with PCR products or genomic DNA was performed as previously described (de la Tour et al. 2011). The genetic structure and the purity of mutant strains were verified by PCR. Oligonucleotides used for constructions of mutants, diagnostic PCR, and sequencing are available upon request.

D. radiodurans bacteria were grown at $30{ }^{\circ} \mathrm{C}$ in TGY2X ( $1 \%$ tryptone, $0.2 \%$ dextrose, $0.6 \%$ yeast extract) or plated on TGY1X containing 1.5\% agar. Media were supplemented with the appropriate antibiotics used at the following concentrations: hygromycin, $50 \mu \mathrm{g} / \mathrm{mL}$; chloramphenicol, $3.5 \mu \mathrm{g} / \mathrm{mL}$; kanamycin, $6 \mu \mathrm{g} / \mathrm{mL}$; tetracycline, $2.5 \mu \mathrm{g} /$ $\mathrm{mL}$, and spectinomycin, $75 \mu \mathrm{g} / \mathrm{mL}$. E. coli was grown in Luria-Bertani medium at $37^{\circ} \mathrm{C}$ with the appropriate antibiotics to the following concentrations: ampicillin, $100 \mu \mathrm{g} /$ $\mathrm{mL}$; kanamycin, $40 \mu \mathrm{g} / \mathrm{mL}$.

Transformation of $D$. radiodurans with plasmid DNA was performed as previously described (de la Tour et al. 2011).

\section{Expression and purification of DdrD protein}

The gene coding for the DR0326 protein, as indicated in Genbank, was amplified from $D$. radiodurans genomic DNA by PCR using primers DR0326us (GGAACAGCA TATGGATACCCTGAAAAAAGCTGGAACGATGC) and DR0326ds (GGAATTCTTAGGCTGCCGGGG TGTTTTCGCCGGCCTCGCTC). The resulting product was inserted into the NdeI and the EcoRI cloning 
Table 1 Bacterial strains and plasmids

\begin{tabular}{|c|c|c|}
\hline Bacterial strains $D$. radiodurans & Description & Source or references \\
\hline R1/GY9613 & Wild type, ATCC 13939 & Laboratory stock \\
\hline GY 15921 & $d d r D:: H A-k a n$ & de la Tour et al. (2013) \\
\hline GY 15951 & ddrD::HA-kan $\Delta i r r E \Omega c a t$ & This work \\
\hline GY14164 & $\Delta d d r O \Omega c a t / p 11891\left(\right.$ prepUTs::ddrO $\left.O^{+}\right)$ & Devigne et al. (2015) \\
\hline GY16922 & [ddrD::HA-kan $\Delta d d r O \Omega$ cat/p11891(prepUTs ::ddrO $\left.\left.O^{+}\right)\right]$ & This work \\
\hline GY15924 & $\Delta d d r D \Omega k a n$ & This work \\
\hline GY15929 & $\Delta d d r C \Omega k a n$ & de la Tour et al. (2017) \\
\hline GY15930 & $\Delta d d r C \Omega c a t$ & This work \\
\hline GY 16936 & $\Delta d d r C \Omega$ hygro & This work \\
\hline GY 16002 & $\Delta d d r A \Omega c a t$ & Laboratory stock \\
\hline GY16926 & $\Delta d d r A \Omega$ hygro & This work \\
\hline GY13915 & $\Delta d d r B \Omega c a t$ & Laboratory stock \\
\hline GY 12835 & $\Delta d d r B \Omega k a n$ & de la Tour et al. (2011) \\
\hline GY16938 & $\Delta d d r B \Omega t e t$ & This work \\
\hline GY16944 & $\Delta d d r A \Omega$ hygro $\Delta d d r B \Omega k a n$ & This work \\
\hline GY16931 & $\Delta d d r A \Omega$ hygro $\Delta d d r C \Omega k a n$ & This work \\
\hline GY16932 & $\Delta d d r A \Omega$ hygro $\triangle d d r D \Omega k a n$ & This work \\
\hline GY15937 & $\Delta d d r B \Omega$ cat $\Delta d d r C \Omega k a n$ & This work \\
\hline GY15936 & $\Delta d d r B \Omega$ cat $\Delta d d r D \Omega k a n$ & This work \\
\hline GY15932 & $\Delta d d r C \Omega$ cat $\Delta d d r D \Omega k a n$ & This work \\
\hline GY16933 & $\Delta d d r A \Omega$ hygro $\Delta d d r C \Omega$ cat $\Delta d d r D \Omega k a n$ & This work \\
\hline GY16934 & $\Delta d d r A \Omega$ hygro $\Delta d d r B \Omega$ cat $\triangle d d r C \Omega$ kan & This work \\
\hline GY16935 & $\Delta d d r A \Omega$ hygro $\Delta d d r B \Omega$ cat $\Delta d d r D \Omega k a n$ & This work \\
\hline GY16937 & $\Delta d d r B \Omega$ cat $\Delta d d r C \Omega$ hygro $\Delta d d r D \Omega k a n$ & This work \\
\hline GY16938 & $\Delta d d r A \Omega$ hygro $\Delta d d r B \Omega$ tet $\Delta d d r C \Omega$ cat $\Delta d d r D \Omega$ kan & This work \\
\hline GY15971 & $\Delta u v r A \Omega c a t$ & de la Tour et al. (2017) \\
\hline GY15972 & $\Delta u v s$ Ehygro & de la Tour et al. (2017) \\
\hline GY15975 & $\Delta d d r D \Omega k a n \Delta u v r A \Omega c a t$ & This work \\
\hline GY15976 & $\Delta d d r D \Omega$ kan $\Delta u v s E \Omega$ hygro & This work \\
\hline GY12251 & $\Delta p p r A \Omega c a t$ & Devigne et al. (2013) \\
\hline GY15934 & $\Delta p p r A \Omega$ cat $\Delta d d r D \Omega k a n$ & This work \\
\hline Plasmids & Description & Source or references \\
\hline p11086 & Source of kan cassette & Laboratory stock \\
\hline pPS6 & Source of cat cassette & Laboratory stock \\
\hline p12625 & Source of hygro cassette & Laboratory stock \\
\hline P11165 & Source of tet cassette & Laboratory stock \\
\hline p12764 & Source of $H A:: k a n$ cassette & Laboratory stock \\
\hline p11891 & p13841:prepUTs::ddrO ${ }^{+}, \operatorname{spec}^{R}$ & Devigne et al. (2015) \\
\hline p11559 & Shuttle vector $E$. coli/D. radiodurans, $\mathrm{Spec}^{\mathrm{R}}$ & Laboratory stock \\
\hline pET21 & Expression vector & Novagen \\
\hline pEAW21 & pET21-DdrD & This work \\
\hline
\end{tabular}

sites of pET21a (Novagen) to yield construct pEAW321. The construct was transformed into the $E$. coli expression strains STL2669 pT7pol26 [ $\Delta($ recA-srlR $) 306:: T n 10$ $x o n A 2\left(s b c B^{-}\right)$, a gift from Susan T. Lovett (Brandeis University, Waltham, MA). pT7pol26 is described in (Lusetti et al. 2003). The cells were grown in $10 \mathrm{~L} \mathrm{LB}$ broth containing $100 \mu \mathrm{g} / \mathrm{mL}$ ampicillin and $40 \mu \mathrm{g} / \mathrm{mL}$ kanamycin at $37{ }^{\circ} \mathrm{C}$ to an $\mathrm{OD}_{600 \mathrm{~nm}}$ of 0.5 . Overexpression of $\mathrm{DdrD}$ was then induced with $0.4 \mathrm{mM}$ IPTG (GoldBio) and grown at $37^{\circ} \mathrm{C}$ for three more hours before harvest. The $13 \mathrm{~g}$ cell pellet was frozen in liquid nitrogen and thawed overnight at $4{ }^{\circ} \mathrm{C}$ in $50 \mathrm{~mL}$ of $\mathrm{R}$ buffer $(20 \mathrm{mM}$ Tris $-\mathrm{Cl} 80 \%$ cations, 
$100 \mu \mathrm{M}$ EDTA, and 10\% w/v glycerol). All subsequent steps were performed at $4{ }^{\circ} \mathrm{C}$. Lyzozyme (Sigma) was added to a final concentration of $0.2 \mathrm{mg} / \mathrm{mL}$. Cells were stirred for $2 \mathrm{~h}$ and then sonicated on ice. Insoluble material and cell debris were pelleted and removed by centrifugation at $38,000 \mathrm{~g}$ for $2 \mathrm{~h}$ and the cell lysate supernatant was precipitated by the dropwise addition of $10 \mathrm{~mL}$ of $5 \% \mathrm{w} / \mathrm{v}$ polyethyleneimine. The solution was stirred for $1 \mathrm{~h}$, then centrifuged for $15 \mathrm{~min}$ at $9000 \mathrm{~g}$. The protein remained in the supernatant. The supernatant was brought to $30 \%$ $\mathrm{NH}_{4}\left(\mathrm{SO}_{4}\right)_{2}$ (MP Biochemical) by addition of solid powder $\left(15 \mathrm{~g} \mathrm{NH}_{4}\left(\mathrm{SO}_{4}\right)_{2}\right.$ to $\left.85 \mathrm{~mL}\right)$. The solution was stirred $1 \mathrm{~h}$, then centrifuged for $30 \mathrm{~min}$ at $25,000 \mathrm{~g}$. The pellet was discarded and the remaining supernatant brought to $40 \%$ saturation by additional $\mathrm{NH}_{4}\left(\mathrm{SO}_{4}\right)_{2}\left(5.49 \mathrm{~g} \mathrm{NH}_{4}\left(\mathrm{SO}_{4}\right)_{2}\right.$ to $90 \mathrm{~mL}$ ). The solution was stirred for $4 \mathrm{~h}$ and centrifuged for $30 \mathrm{~min}$ at $25,000 \mathrm{~g}$. The DdrD protein remained in the pellet and was eluted from the pellet using $\mathrm{R}$ buffer containing $1 \mathrm{M} \mathrm{NH}_{4}\left(\mathrm{SO}_{4}\right)_{2}$. The resuspended protein was then loaded on a $120 \mathrm{~mL}$ Butyl Sepharose (Amersham) column using an AKTA FPLC system. DdrD bound to the butyl column and was eluted by a gradient from $\mathrm{R}$ buffer containing $1 \mathrm{M} \mathrm{NH}_{4}\left(\mathrm{SO}_{4}\right)_{2}$ to $\mathrm{R}$ buffer only, through 10 column volumes. The protein eluted at a concentration of around $700 \mathrm{mM} \mathrm{NH}{ }_{4}\left(\mathrm{SO}_{4}\right)_{2}$ in buffer R. Fractions containing $\mathrm{DdrD}$ were pooled $(90 \mathrm{~mL})$ and brought to $50 \% \mathrm{NH}_{4}\left(\mathrm{SO}_{4}\right)_{2}$ saturation by the addition of $38 \mathrm{~g}$ of $\mathrm{NH}_{4}\left(\mathrm{SO}_{4}\right)_{2}$. The solution was centrifuged at $25,000 \mathrm{~g}$ for $30 \mathrm{~min}$, and the pellet resuspended in $10 \mathrm{~mL} \mathrm{R}$ buffer. The resuspended protein solution was dialyzed 4 times $2 \mathrm{~h}$ against $\mathrm{R}$ buffer and loaded on a $25 \mathrm{~mL}$ DEAE column. DdrD binds poorly to the DEAE column and was recovered in the flow through in a cleaner state. The flow through containing DdrD was dialyzed in $\mathrm{R}$ buffer and loaded on a $20 \mathrm{~mL}$ SP Sepharose column. DdrD binds poorly to the SP Sepharose and was recovered from the flow through. The $75 \mathrm{~mL}$ flow through was dialyzed 4 times against $2 \mathrm{~L}$ of $\mathrm{P}$ buffer ( $20 \mathrm{mM}$ phosphate buffer) and loaded onto a $20 \mathrm{~mL}$ hydroxyapatite (HAP) column. A gradient of five column volumes to reach $1 \mathrm{M}$ phosphate buffer was applied. DdrD also binds poorly to the HAP, the flow through was dialyzed 4 times $2 \mathrm{~h}$ against $2 \mathrm{~L}$ of $\mathrm{R}$ buffer $+1 \mathrm{M} \mathrm{NH}_{4}\left(\mathrm{SO}_{4}\right)_{2}$. DdrD was then loaded onto a $120 \mathrm{~mL}$ Butyl column, one column volume was applied to wash the column to elute and concentrate the protein in one step by going directly to $\mathrm{R}$ buffer. The elution fractions $(\sim 120 \mathrm{~mL})$ were pooled and concentrated to $5 \mathrm{~mL}$ with a Centricon Plus 20 (Merck Millipore). The protein concentration was determined by measuring the absorbance at $280 \mathrm{~nm}$ and using the calculated extinction coefficient $\varepsilon_{\mathrm{DdrD}}=5120 \mathrm{M}^{-1} \mathrm{~cm}^{-1}\left(0.2420(\mathrm{mg} / \mathrm{mL})^{-1} \mathrm{~cm}^{-1}\right)$. It was estimated at $5.4 \mathrm{mg} / \mathrm{mL}$ or $254 \mu \mathrm{M}$. Mass spectrometry analysis (MALDI-TOF) confirmed the purified protein was the expected $21.1 \mathrm{kDa} D$. radiodurans DR0326 DdrD. The purified protein was free of any detectable nuclease activity. The undiluted protein was flash frozen in $20 \mu \mathrm{L}$ aliquots and stored at $-80{ }^{\circ} \mathrm{C}$.

\section{Glutaraldehyde treatment}

Purified DdrD and DdrC proteins were diluted in a buffer containing $50 \mathrm{mM}$ Tris- $\mathrm{HCl} \mathrm{pH} 8,15 \%$ (V/V) glycerol, and $1 \mathrm{mM}$ DTT. They were incubated with $0.1 \%$ glutaraldehyde in $10 \mathrm{mM}$ sodium phosphate buffer $(\mathrm{pH} 7)$ at $30{ }^{\circ} \mathrm{C}$ for $30 \mathrm{~min}$ in a final volume of $20 \mu \mathrm{L}$. After incubation, $5 \mu \mathrm{L}$ of $5 \mathrm{X}$ Laemmli buffer (312.5 mM Tris- $\mathrm{HCl} \mathrm{pH} 6.8$, $50 \%$ glycerol, $10 \%$ SDS, 250 mM DTT, $0.1 \%$ bromophenol blue) were added and the samples were analyzed by electrophoresis through a $15 \%$ SDS-polyacrylamide gel, followed by Coomassie blue staining. DdrC protein used as a positive control is a gift of J. Timmins (Univ Grenoble Alpes, France),

\section{$\gamma$-irradiation of $D$. radiodurans bacteria}

A saturated bacterial culture was diluted in fresh TGY2X medium and incubated at $30{ }^{\circ} \mathrm{C}$ to an $A_{650 \mathrm{~nm}}=0.3$. Cells were then concentrated to $A_{650 \mathrm{~nm}}=20$ by centrifugation and exposed to $5 \mathrm{kGy}$ or $8 \mathrm{kGy} \gamma$-irradiation on ice $\left({ }^{137} \mathrm{Cs}\right.$ irradiation system GSR-D1, dose rate 18.5 Gy/min, Institut Curie, Orsay). Following irradiation, diluted cells were plated on TGY plates. Colonies were counted after 3-5 days incubation at $30^{\circ} \mathrm{C}$.

\section{UV irradiation of $D$. radiodurans bacteria}

The UV sensitivity of $D$. radiodurans bacteria was tested on plates. Cultures of exponentially growing cells at an $A_{650 \mathrm{~nm}}=0.3$ were serially diluted $1: 10$ in TGY2X broth and aliquots $(10 \mu \mathrm{L})$ of each dilution were spotted on TGY1X agar plates. The plates were exposed to different doses of UV radiation using a UV-C lamp emitting at a calibrated dose rate of $3.5 \mathrm{~J} \mathrm{~m}^{-2} \mathrm{~s}^{-1}$ and incubated at $30{ }^{\circ} \mathrm{C}$ for $3-5$ days.

\section{Western blot analysis of HA-tagged DdrD protein}

Non-irradiated or irradiated cultures ( $5 \mathrm{kGy}$ ) of $D$ radiodurans producing the DdrD-HA protein were diluted in $120 \mathrm{~mL}$ TGY2X broth to an $A_{650 \mathrm{~nm}}=0.2$ and incubated at $30{ }^{\circ} \mathrm{C}$ with shaking. Aliquots of $15 \mathrm{~mL}$ were taken at different times and centrifuged. The cell pellets were resuspended in $150 \mu \mathrm{L} 1 \mathrm{X}$ SSC buffer $(150 \mathrm{mM} \mathrm{NaCl}, 15 \mathrm{mM}$ trisodium citrate, $\mathrm{pH} 7$ ) and cell extracts were prepared as previously described (de la Tour et al. 2009). $10 \mu \mathrm{g}$ of crude extracts were resolved in $12 \%$ SDS-PAGE gels and transferred onto a PVDF membrane (GE Healthcare). The membranes were 
incubated overnight at $4{ }^{\circ} \mathrm{C}$ with a 1:5000 dilution of monoclonal mouse anti-HA antibodies (Eurogentec), and then $1 \mathrm{~h}$ at room temperature with a secondary alkaline phosphataselabeled anti-mouse antibody, and revealed by a colorimetric reaction using nitroblue tetrazolium (NBT) and 5-bromo4-chloro-3-indolyl phosphate (BCIP) as substrates for the alkaline phosphatase (Promega).

\section{DdrO depletion}

D. radiodurans strain GY16922 [ddrD::HA-kan $\Delta d d r O \Omega$ catlp11891 $\left(\right.$ prep $\left.\left._{T S} d d r O^{+}\right)\right]$was grown at a permissive temperature $\left(30{ }^{\circ} \mathrm{C}\right)$ in TGY2X medium supplemented with chloramphenicol and spectinomycin. Cultures at an $A_{650}=0.3$ were centrifuged and cell pellets were resuspended in the same volume of fresh culture medium supplemented with chloramphenicol. Then, cells were grown at permissive $\left(30{ }^{\circ} \mathrm{C}\right)$ or non-permissive $\left(37^{\circ} \mathrm{C}\right)$ temperature to allow replication or not of the repU $\mathrm{T}_{\mathrm{Ts}}$ plasmid. Aliquots of $20 \mathrm{~mL}$ were taken for western blot analyses after $4 \mathrm{~h}, 8 \mathrm{~h}$, and $16 \mathrm{~h}$ incubation.

\section{Electrophoretic mobility shift assay (EMSA)}

Synthesized DNA substrates were purchased from Integrated DNA Technologies or Eurofins. The sequence of the 67-mer oligonucleotide, arbitrarily selected from the M13 phage genome, was 5'-CTGTTTAAGAAATTCACCTCGAAA GCAAGCTGATAAACCGATACAATTAAAGGCTCCTTT TGGAGCC-3'. The sequence of the corresponding 67 mer reverse oligonucleotide was: 5'-GGCTCCAAAAGGAGC CTTTAATTGTATCGGTTTATCAGCTTGCTTTCGAGG TGAATTTCTTAAACAG-3'.

Binding of DdrD protein to oligonucleotides was performed using a single-stranded 5' Cy5-labeled 67 mer oligonucleotide (oligo 1) or the corresponding double-stranded 67 mer substrate (oligo 2). To generate the ds 67 mer substrate (oligo 2), 1 pmol of labeled 67 mer oligonucleotide and 1 pmol of 67 mer reverse oligonucleotide were mixed together in a buffer (20 mM Tris- $\mathrm{HCl} \mathrm{pH} \mathrm{7.5,50} \mathrm{mM} \mathrm{NaCl),}$ heated at $95{ }^{\circ} \mathrm{C}$ for $2 \mathrm{~min}$, and cooled for $2 \mathrm{~h}$ at room temperature. Double-stranded substrates with a $37-n t 5^{\prime}$ tail (oligo 3) or with a 37-nt 3' tail (oligo 4) were generated by annealing oligo 1 with either the 30-mer oligonucleotide (5'GGCTCCAAAAGGAGCCTTTAATTGTATCGG-3') or the 30-mer oligonucleotide (5'-GCTTGCTTTCGAGGTGAA TTTCTTAAACAG-3'), respectively. All reactions were performed in $15 \mu \mathrm{L}$ of buffer A (40 mM Tris- $\mathrm{HCl} \mathrm{pH} 7.8$, $5 \mathrm{mM} \mathrm{MgCl} 2,1.5 \mathrm{mM}$ DTT, $50 \mathrm{mM} \mathrm{NaCl}, 2.5 \%$ glycerol) containing 50 fmoles $(3.3 \mathrm{nM})$ of DNA. The reaction was initiated by adding the DdrD protein at the indicated final concentrations. The mixture reaction was incubated at $4{ }^{\circ} \mathrm{C}$ for $15 \mathrm{~min}$ and loaded onto $6 \%(\mathrm{w} / \mathrm{v})$ native polyacrylamide gels (19:1 (w/w) acrylamide/bisacrylamide) in 0.25X TBE buffer (Tris/Borate/EDTA) containing 10\% (V/V) glycerol. The gels were pre-run before loading the reaction mixtures. After migration at $15 \mathrm{~V} / \mathrm{cm}$ for $135 \mathrm{~min}$ at $4{ }^{\circ} \mathrm{C}$, bands were visualized by scanning with a Typhoon phosphorimager (Typhoon Trio Imager, GE Healthcare).

\section{Nuclease protection assays}

The assays were performed with $1 \mathrm{U}$ DNase I (Promega) or $30 \mathrm{U}$ RecJ (New England Biolabs). $3.3 \mathrm{nM}$ of doublestranded oligonucleotide with the 37 -nt $5^{\prime}$ tail (oligo 3 ) was used in the nuclease assays with DNase I. For the assay with RecJ, the 3' Cy5-labeled 67-mer oligonucleotide was used to generate the corresponding dsDNA substrate (oligo 5). DNA was pre-incubated with $\operatorname{DdrD}$ protein $(8 \mu \mathrm{M})$ for $15 \mathrm{~min}$ at $4{ }^{\circ} \mathrm{C}$ in $16 \mu \mathrm{L}$ of buffer $\mathrm{A}$. Then, $4 \mu \mathrm{L}$ of $5 \mathrm{X}$ nuclease buffer containing or not, nucleases were added and further incubated for $15 \mathrm{~min}$ at $30^{\circ} \mathrm{C}$ for DNase I or for $30 \mathrm{~min}$ at $37{ }^{\circ} \mathrm{C}$ for RecJ. 5X RecJ nuclease buffer contains $100 \mathrm{mM}$ Tris $\mathrm{HCl}$ $\mathrm{pH} 7.9,100 \mathrm{mM} \mathrm{NaCl}$, and $25 \mathrm{mM} \mathrm{MgCl}_{2}$ and $5 \mathrm{X}$ DNase nuclease buffer contains $200 \mathrm{mM}$ Tris $\mathrm{HCl} \mathrm{pH} 8,50 \mathrm{mM}$ $\mathrm{MgSO}_{4}$, and $5 \mathrm{mM} \mathrm{CaCl}_{2}$. After addition of loading buffer, samples were loaded onto native polyacrylamide gels as described above.

\section{Pulsed field gel electrophoresis}

D. radiodurans exponential phase cultures were concentrated to an $A_{650 \mathrm{~nm}}=20$ in $10 \mathrm{mM} \mathrm{MgSO} \mathrm{m}_{4}$ before irradiation. Then, non-irradiated (NI) or irradiated (5 kGy) cultures were diluted in TGY2X or $10 \mathrm{mM} \mathrm{MgSO}_{4}$ to an $A_{650 \mathrm{~nm}}=0.2$ and incubated at $30{ }^{\circ} \mathrm{C}$. At different post-irradiation incubation times, culture aliquots $(5 \mathrm{~mL})$ were removed to prepare DNA plugs as previously described (Harris et al. 2004), except that each agarose embedded DNA plug was digested for $5 \mathrm{~h}$ at $37{ }^{\circ} \mathrm{C}$ with 1 unit (FDU) of FastDigest NotI restriction enzyme before being subjected to pulsed field gel electrophoresis.

\section{Results and discussion}

\section{The expression of DdrD protein is induced after irradiation and is under control of IrrE/DdrO regulatory proteins}

Transcriptomic analyses have previously shown that expression of the $d d r D$ gene is induced 8-13 fold after an exposure to $3 \mathrm{kGy}$ of $\gamma$ rays and 6-9 fold after desiccation (Tanaka et al. 2004). The analysis of the D. radiodurans genome predicts that the $d d r D$ gene [ $d r 0326$, in the previous annotation (White et al. 1999) and A2G07_11905 in the new 
annotation (Hua and Hua 2016)] encodes a protein of 198 amino acids (Mw: 21.200) beginning by an ATG initiation codon (Fig. S1a). The multiple sequence alignment of DdrD proteins from Deinococcus genera isolates showed that the D. radiodurans DdrD protein exhibits a high similarity with its homologs in Deinococcus ( $>50 \%$ of identity), located predominantly in the first $120 \mathrm{~N}$-terminal amino acids (Fig. S1b).

A potential promoter sequence can be discerned with - 35 and - 10 elements (Fig. S1a). RNA-seq analysis of Deinococcus deserti, complemented by proteomic studies showed that the $d d r D, d d r A$, and $d d r C$ genes are translated from leaderless mRNA and the TSS (Transcription Start Site) corresponds to the first base of the translation initiation codon (de Groot et al. 2014). It is likely that the $D$. radiodurans $d d r D$ gene is also translated from a leaderless mRNA, lacking the Shine-Dalgarno sequence involved in ribosome binding. It was predicted that, in $D$. radiodurans, $46 \%$ of proteins could be translated from leaderless RNA (Zheng et al. 2011), and the authors proposed a correlation between radiation tolerance and leaderless translation initiation. High level of genes without translation leaders in Deinococcus species may be important in their adaptation to extreme environmental conditions.

An RDRM sequence, the binding site of repressor DdrO (Blanchard et al. 2017; Wang et al. 2015), was found 10 nt upstream of the putative start codon of the $d d r D$ gene (Fig. S1a). To test if the expression of the DdrD protein is under the control of the IrrE and DdrO regulator proteins, we analyzed the kinetics of expression of DdrD after exposure to $\gamma$-rays in cells lacking IrrE. For this purpose, the DdrD protein was tagged at its $\mathrm{C}$-terminus with the HA epitope and expressed in replacement of the native DdrD protein. Its expression was followed after a $5 \mathrm{kGy} \gamma$-irradiation in a wild type strain and in a $\triangle i r r E$ mutant. The presence of the HATag in the C-terminal part of the protein slightly modified its migration on SDS-PAGE (Fig. 1). Western blot analysis showed a basal level expression of DdrD-HA in unirradiated cells that strongly increased after irradiation in wild type cells but it remained constant in the cells devoid of IrrE protein (Fig. 1a). This result shows that IrrE is a positive regulator of $d d r D$ gene, correlating with previous transcriptomic approaches (Lu et al. 2012). We also examined the effect of $\mathrm{DdrO}$ depletion on the expression of DdrD-HA. As $d d r O$ is an essential gene (Devigne et al. 2015), we used a $\Delta d d r O$ mutant strain expressing $d d r O$ from a prep $\mathrm{U}_{\text {ts }}$ plasmid and compared the kinetics of expression at $30{ }^{\circ} \mathrm{C}$ and at $37{ }^{\circ} \mathrm{C}$, a non-permissive temperature for replication of the plasmid. The depletion of the $\mathrm{DdrO}$ protein at $37{ }^{\circ} \mathrm{C}$ resulted in an increase of cellular levels of the DdrD-HA protein (Fig. 1b), strongly suggesting that $\mathrm{DdrO}$ is a repressor of the expression of DdrD. Taken together, these results confirmed that the DdrD protein belongs to the RDR regulon and that its
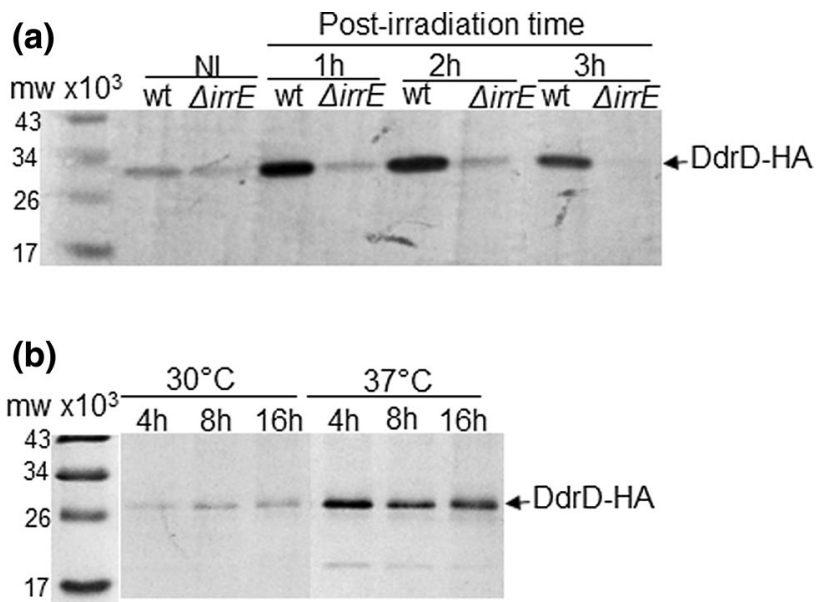

Fig. 1 Expression of the DdrD protein is regulated by the IrrE and DdrO proteins. a Post-irradiation kinetics of GY15921: ddrD ::HA (wt) or GY15951: $d d r D:: H A \Delta \operatorname{irrE}(\Delta \operatorname{irr} E$ ) cells exposed to $5 \mathrm{kGy}$ $\gamma$-irradiation. After irradiation, the cells were incubated for the indicated times and cell extracts were subjected to SDS-PAGE and analyzed by western blotting with anti-HA antibodies. NI

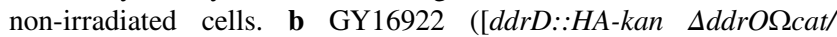
p11891(prepUTs::ddr $\mathrm{O}^{+}$)]) cells grown at $30{ }^{\circ} \mathrm{C}$ in TGY2X broth supplemented with spectinomycin to $A_{650}=0.3$ were harvested and then diluted in a medium without antibiotic and incubated at $30{ }^{\circ} \mathrm{C}$ or $37^{\circ} \mathrm{C}$ for the indicated times (hours). Cell extracts were subjected to SDS-PAGE and analyzed by western blotting with anti-HA antibodies. Ten $\mu \mathrm{g}$ of protein extract were loaded in each well

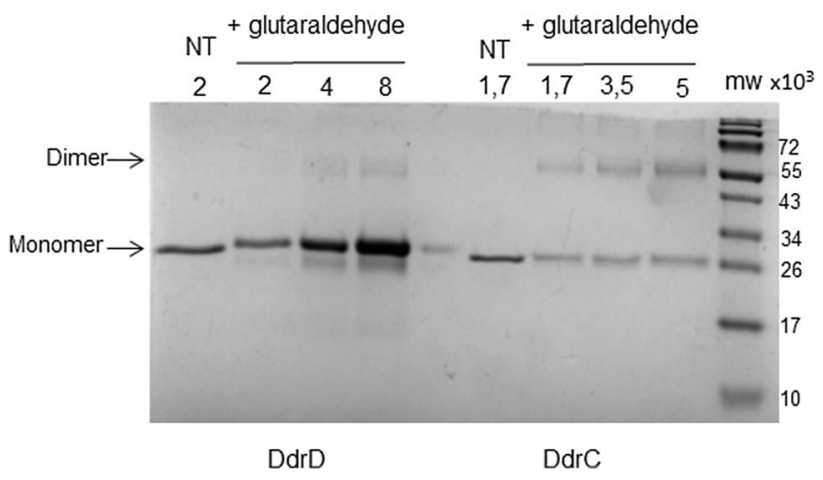

Fig. 2 DdrD protein is a monomer in solution. Increasing amounts of DdrD or DdrC proteins $(\mu \mathrm{M})$ were crosslinked with glutaraldehyde. $N T$ non-treated protein, $M$ molecular weight markers

expression is under the control of the IrrE/DdrO regulatory proteins.

\section{DdrD binds to ssDNA and to dsDNA with a single-stranded $5^{\prime}$ extension}

To analyze the DNA binding properties of DdrD, we first determined the oligomeric state of the native purified DdrD in solution. Previous studies showed that DdrA exhibits a heptameric (Gutsche et al. 2008), DdrB a pentameric (Norais 
et al. 2009) and DdrC a dimeric structure in solution (de la Tour et al. 2017). As shown in SDS-PAGE analysis (Fig. 2), DdrD migrates approximately to the size deduced from the amino acid sequence. In the presence of glutaraldehyde used as a crosslinking agent, an intense band corresponding to the monomeric form of DdrD was observed on the gel while two bands corresponding both to the monomeric and dimeric forms were observed for DdrC as previously shown (de la Tour et al. 2017). At a DdrD concentration $>4 \mu \mathrm{M}$, only faint bands attributed to dimeric forms were visible, indicating that DdrD is mainly present in a monomeric form in solution.

The DNA binding properties of DdrD were then investigated using electrophoretic mobility shifts assays. First, we observed that, contrary to the results obtained with DdrC (de la Tour et al. 2017), no DNA shift was visible when DdrD was incubated with large DNAs such as circular phiX174 ssDNA or linearized phiX174 dsDNA (Fig. S2). However, a DNA shift was observed when a single-stranded 67 mer oligonucleotide (oligo 1) was used as a substrate (Fig. 3a). Faint bands, likely corresponding to larger DdrD/DNA complexes, were observed at 4 and $8 \mu \mathrm{M}$ but the DNA was not completely shifted even at the highest DdrD concentration. Removal of DdrD by treatment with proteinase K (lane $8+\mathrm{PK}$ ) released the DNA substrate from the nucleoprotein complexes, indicating that the DNA was intact. On the other hand, the corresponding double-stranded 67mer oligonucleotide (oligo 2) was not shifted by DdrD at the same concentrations (Fig. 3b). Thus, DdrD specifically interacts with ssDNA, as previously reported for DdrA (Harris et al. 2008) and DdrB (Norais et al. 2009). DdrC also exhibits a preference for ssDNA (de la Tour et al. 2017).
Fig. 3 DdrD protein binds to ssDNA and dsDNA with a $5^{\prime}$ extension. Increasing concentrations of DdrD were incubated with the indicated DNA substrates (oligos 1, 2, 3, or 4) and the products of the reactions were separated by electrophoresis through $6 \%$ native polyacrylamide gels $(\mathbf{a}, \mathbf{b}, \mathbf{c}, \mathbf{d})$. On a, lane $8+\mathrm{PK}$ corresponds to the reaction of lane 8 treated with a mixture of $1 \mathrm{mg} / \mathrm{mL}$ Proteinase K/0.5\% SDS. Lanes 0: DNA controls without DdrD. Dots indicate the position of the Cy5 label

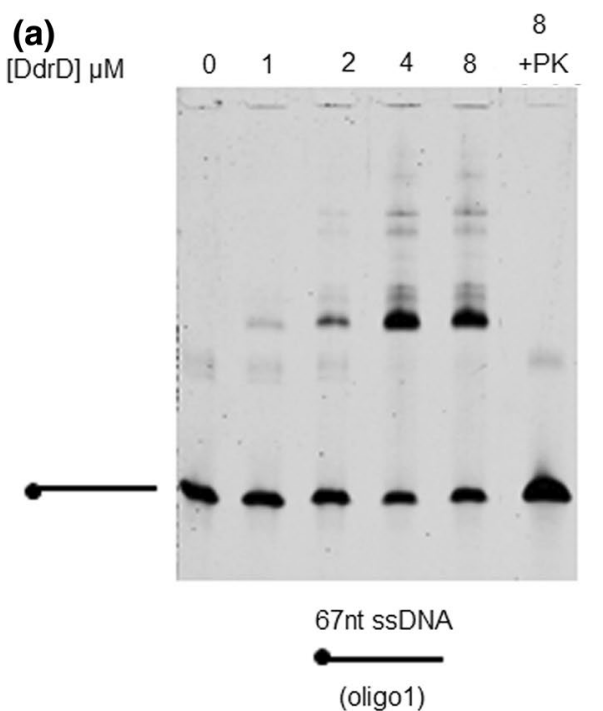

(c)

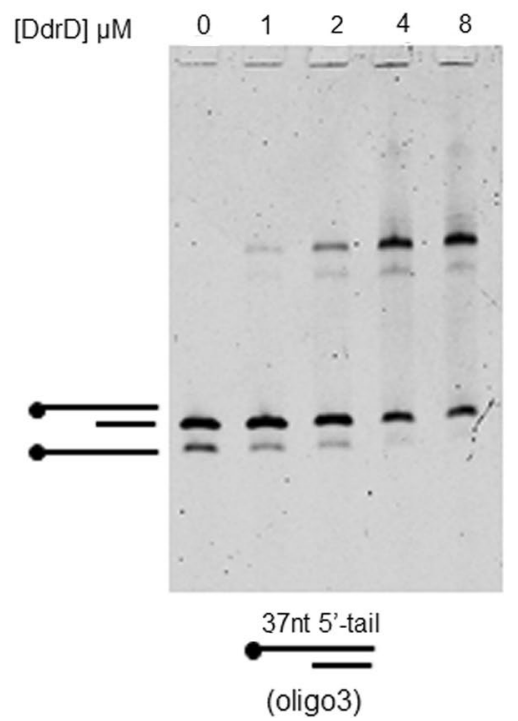

(b)

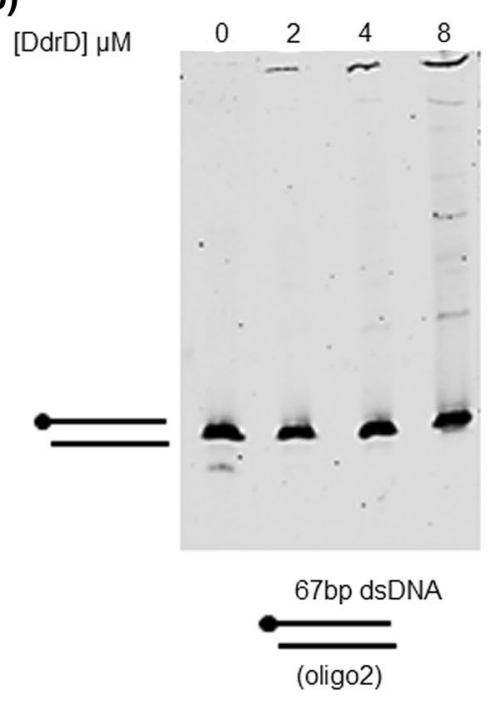

(d)

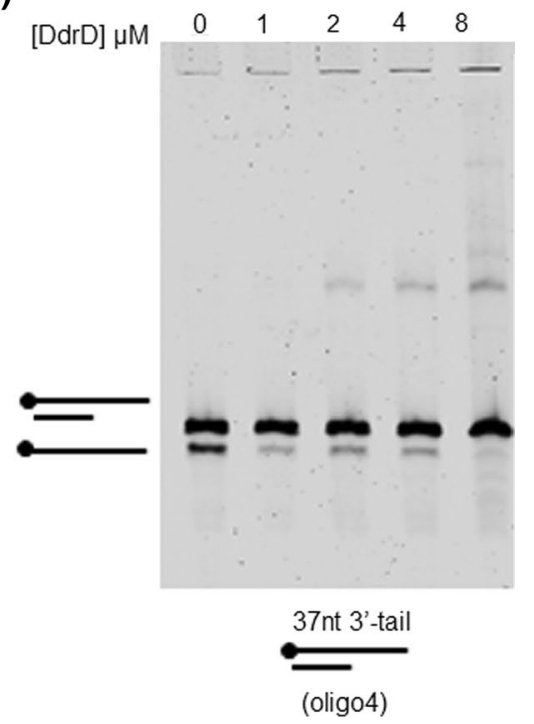


To further investigate DdrD-ssDNA interactions, we tested DdrD's ability to bind to a double-stranded oligonucleotide with a single-stranded $5^{\prime}$ or $3^{\prime}$ extension (oligos 3 and 4). When oligo 3 (ds oligonucleotide with a 37-nt 5' tail) was tested, two shifted bands were visible (Fig. 3c) likely corresponding to both the binding of DdrD to oligo 3 (major band) and to the remaining fraction of non-hybridized ssDNA (minor band) present in the preparation of the substrate and that interacts with DdrD. On the other hand, when oligo 4 (ds oligonucleotide with a 37-nt 3' tail) was tested, only the faint shifted band corresponding to the DdrD-ssDNA complex was observed (Fig. 3d). Thus, DdrD exhibits some preference for the 5 '-ssDNA extension while DdrA preferentially binds to a 3 '-ssDNA extension (Harris et al. 2004, 2008) suggesting that the two proteins could protect the DNA ends generated after $\gamma$-irradiation.

Therefore, we investigated DdrD's ability to protect the $5^{\prime}$ tail of dsDNA from nucleases (Fig. 4). DdrD protein was incubated either with oligo 5 prior to the addition of RecJ, an exonuclease that digests ssDNA from the $5^{\prime}$ end, or with oligo 3 prior the addition of DNase I, an endonuclease that digests single- and double-stranded DNA. We observed that the presence of DdrD, even at a high concentration $(8 \mu \mathrm{M})$, does not protect DNA from degradation by RecJ (Fig. 4a, lanes 2 and 4), and only a partial protection could be observed with DNase I (Fig. 4b, lanes 2 and 4). These results suggested that the DdrD does not prevent access of nucleases to DNA. Thus, our in vitro studies showed that DdrD protein binds to ssDNA with a preference for $5^{\prime}$ ends but does not appear to protect DNA from nuclease attack.

\section{The DdrD protein contributes in vivo to genome recovery after $\boldsymbol{\gamma}$-irradiation in nutrient-poor conditions}

To know whether DdrD, like DdrA, plays an in vivo role in the reconstitution of the $D$. radiodurans genome after irradiation, we measured the kinetics of reconstitution of genomic DNA in $\Delta d d r D$ cells exposed to $5 \mathrm{kGy} \gamma$-rays. Recovery from damage was monitored by appearance of the pattern of 11 NotI digested fragments following irradiation, analyzed by pulsed field gel electrophoresis. When post-irradiation recovery of cultures was followed in a rich medium, the pattern of reconstitution of a $\Delta d d r D$ mutant was identical to that of wild type strain (Fig. 5a). Under these conditions, the genome was reconstituted in approximately $2 \mathrm{~h}$ post-irradiation. However, if the cultures were resuspended in $10 \mathrm{mM} \mathrm{MgSO}_{4}$ after irradiation, only a partial reconstitution was visible $24 \mathrm{~h}$ post-irradiation in the wild type cultures (Fig. 5b), whereas there was no evidence of DNA fragment reassembly in $\Delta d d r D$ cultures at $24 \mathrm{~h}$. From $48 \mathrm{~h}$ post-irradiation, a high molecular weight band appeared in wild type cells that was absent in $\Delta d d r D$ cells, indicating that the reconstitution of genomic DNA in cells devoid of DdrD was affected. After $96 \mathrm{~h}$, the DNA reconstruction pattern did not changed in $\Delta d d r D$ cells (Fig. 5b) and remained the same when the post-irradiation time was extended up to $120 \mathrm{~h}$ (Fig S3). These observations suggested that DdrD, as observed for DdrA (Harris et al. 2004), contributes to genome reconstitution after irradiation when cultures are incubated under starvation conditions, In a medium devoided of carbon source, the DNA repair mechanisms are much less efficient than in a rich medium, as it is important to protect DNA during
Fig. 4 DdrD protein does not protect the $5^{\prime}$ tail of dsDNA from degradation by nucleases. The nuclease protection assays were performed using doublestranded oligonucleotide with a 37-nt $5^{\prime}$ tail as the substrate ("Materials and methods"). a Ds oligonucleotide labeled at the 3 ' end (oligo 5) was incubated with DdrD before addition of RecJ. b Ds oligonucleotide labeled at the $5^{\prime}$ end (oligo 3 ) was incubated with DdrD before addition of DNase I. Lanes 1: DNA controls without protein. Lanes 2: DNA incubation with nuclease alone. Lanes 3: DNA incubation with DdrD alone. Lanes 4: DNA pre-incubated with $\operatorname{DdrD} 15$ min at $4{ }^{\circ} \mathrm{C}$ before addition of nuclease
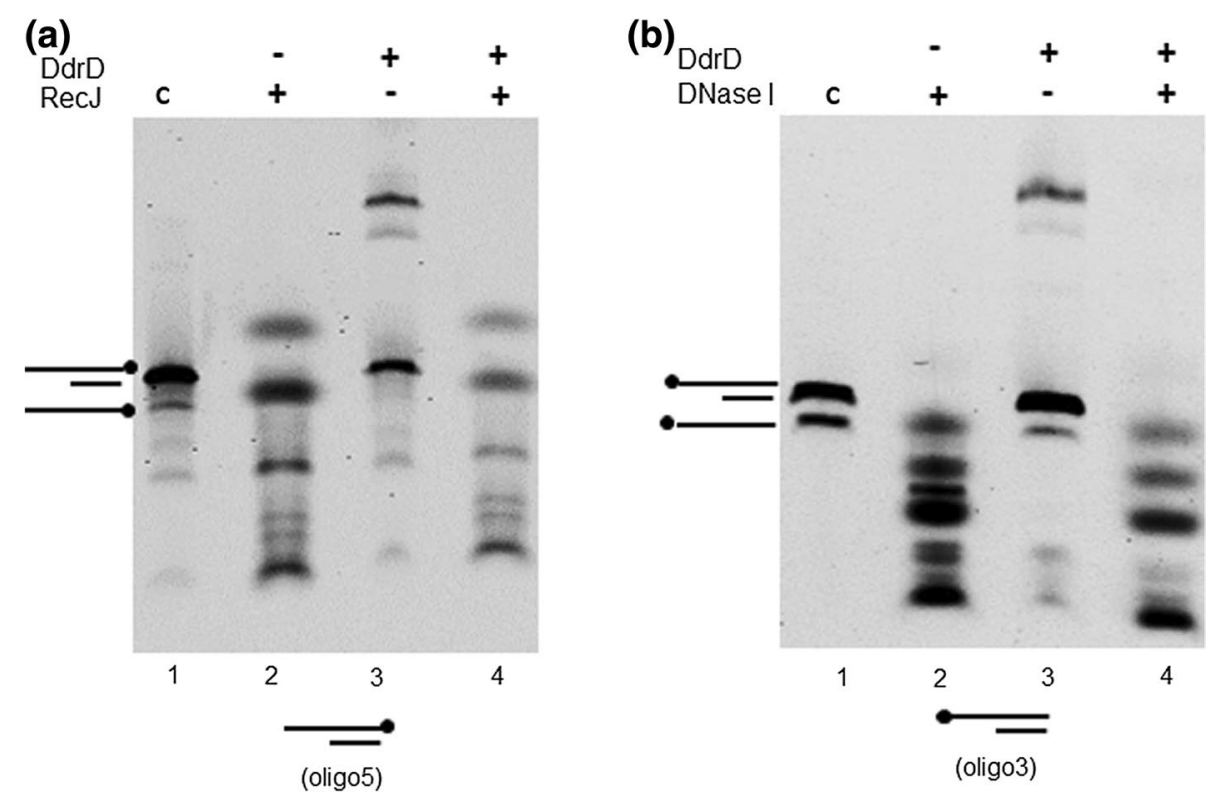
(a)

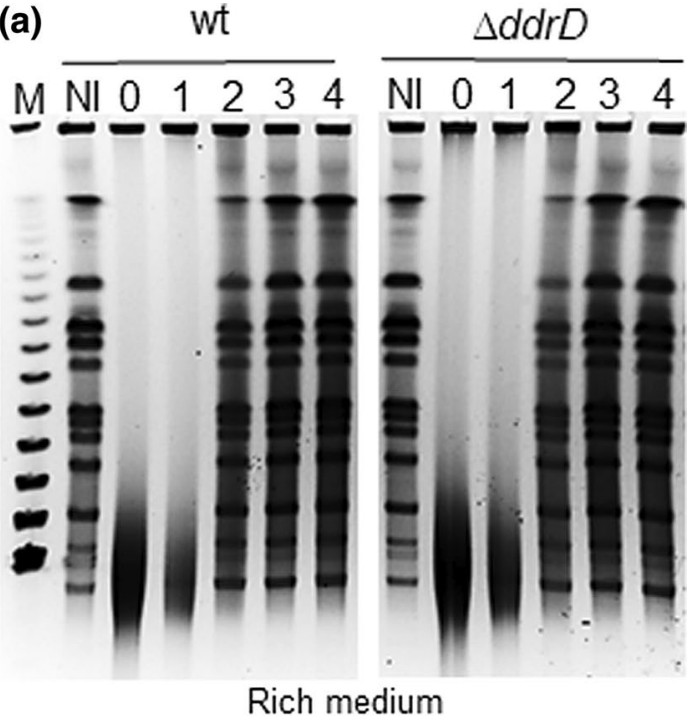

(b)

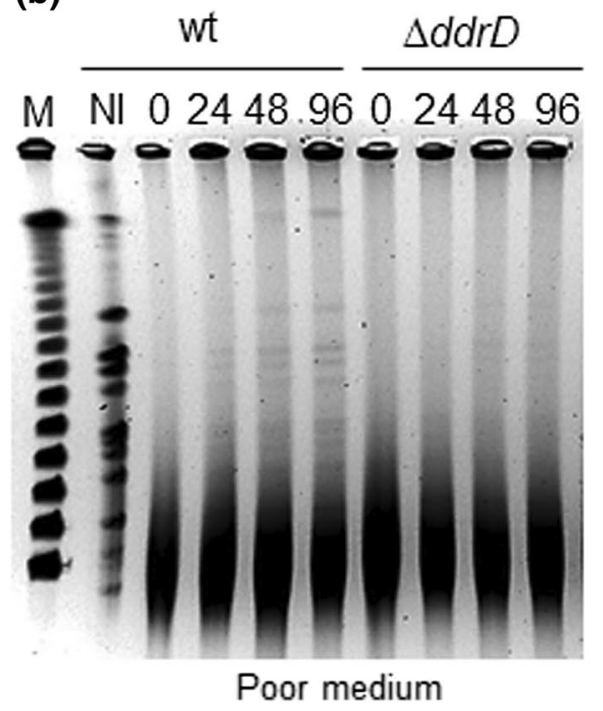

Fig. 5 Kinetics of genome reconstitution in wild type and a $\Delta d d r D$ mutant after $\gamma$-irradiation. Cells were exposed to $5 \mathrm{kGy} \gamma$-irradiation and genome reconstitution was followed by pulsed field electrophoresis of NotI treated DNA at the indicated incubation times (hours). a After irradiation, cells were incubated in a rich medium (TGY2X). b After irradiation, cells were incubated in $10 \mathrm{mM} \mathrm{MgSO}_{4}$. On each panel, lanes NI control of non-irradiated cells, M $\lambda$ DNA fragment ladder $(\mathrm{Kb})$

genome reconstitution. Although, in vitro, DdrD did not appear to protect DNA from nuclease attack (Fig. 4), it could nevertheless, via its properties of binding to the ssDNA and particularly to 5' ssDNA extension (Fig. 3) be a part of the $D$. radiodurans genome-protection system composed of the other single-stranded DNA binding proteins, DdrA, DdrB, and DdrC (de la Tour et al. 2017; Harris et al. 2004; Norais et al. 2009; Xu et al. 2010).

\section{Comparison of the resistance to $\mathrm{Y}$ - and UV irradiation of all possible combinations of $d d r A$, $d d r B, d d r C$, and ddrD mutants}

We focused our work on $d d r$ genes coding for DNA binding proteins that bind preferentially to ssDNA. Previous studies showed that the $d d r A, d d r B, d d r C$, and $d d r D$ genes were among the genes whose expression was most strongly induced in response to stress (Tanaka et al. 2004) but only the deletion of $d d r B$ and, at a much lower level that of $d d r A$, reduced the sensitivity of the mutants to $\gamma$-irradiation. The absence of one of these genes did not significantly affect the sensitivity to UV radiation (Selvam et al. 2013). Here, we analyzed the response to gamma and UV irradiation of mutant strains generated by deletion of all possible combinations of $d d r A, d d r B, d d r C$, and $d d r D$ genes. We compared cell survival of single, double, triple mutants, and the quadruple mutant (Fig. 6). As previously shown (Tanaka et al. 2004), the single $\Delta d d r A, \Delta d d r C$, and $\Delta d d r D$ mutants did not exhibit a significant decrease of radioresistance when exposed to $8 \mathrm{kGy}$ gamma irradiation (Fig. 6a). At this dose of irradiation, only the $\Delta d d r B$ mutant was about 15 -fold more sensitive than the wild type strain. The survival of double mutants showed that only the double deletion of the $d d r A$ and $d d r B$ genes resulted in a drastic decrease (about 70-fold) in gamma irradiation resistance of the mutant strain compared to the single $\Delta d d r B$ mutant. The $\Delta d d r B \Delta d d r C$ and $\Delta d d r B \Delta d d r D$ double mutants exhibited the same sensitivity to this gamma irradiation dose as the $\Delta d d r B$ single mutant. The $\Delta d d r A \Delta d d r C$ and $\Delta d d r A \Delta d d r D$ double mutants had the same sensitivity as the $\Delta d d r A$ single mutant and the $\Delta d d r C$ $\triangle d d r D$ double mutant was as resistant as the wild type strain. The addition of $d d r C$ or $d d r D$ gene deletions in the $\Delta d d r A$ $\Delta d d r B$ double mutant did not increase sensitivity to irradiation when compared to the double mutant, and the deletion of $d d r A$ or $d d r B$ in the $\triangle d d r C \Delta d d r D$ double mutant led to a $\gamma$-ray sensitivity comparable to that of $\Delta d d r A$ or $\Delta d d r B$ single mutants, respectively. Lastly, the quadruple mutant displayed the same cell survival as the $\Delta d d r A \Delta d d r B$ double mutant.

When the different mutant strains were exposed to a dose of $600 \mathrm{~J} \mathrm{~m}^{-2}$ of $\mathrm{UV}$ irradiation (Fig. 6b), the $\Delta d d r A \Delta d d r B$ double mutant was approximatively tenfold more sensitive to UV than the $\Delta d d r \mathrm{~B}$ mutant, but the deletion of $d d r C$ or $d d r D$ genes in the $\Delta d d r A \Delta d d r B$ double mutant had no significant effect on the UV sensitivity. A similar response to UV exposure was observed in the quadruple mutant.

These results confirm that the DdrA and DdrB proteins contribute to $D$. radiodurans radioresistance with $\mathrm{DdrB}$ playing a major role in this radioresistance. On the other hand, the functions of the DdrC and DdrD proteins remain unclear. Previous studies (de la Tour et al. 2017) showed that a $\Delta d d r C$ mutant was UV sensitive when cells were exposed to UV doses 
Fig. 6 Survival of wild type and mutants generated by deletions of all possible combinations of the $d d r A, d d r B, d d r C$, and $d d r D$ genes. a Survival after exposure to $8 \mathrm{kGy} \gamma$-irradiation. The values are the mean of three experiments. They were normalized relative to that of the wild type strain (wt) taken as $100 \%$. b Survival after exposure to $600 \mathrm{~J} \mathrm{~m}^{-2} \mathrm{UV}$ irradiation. Serial dilutions of cultures were spotted on TGY agar plates and exposed to UV irradiation. On each panel, the dots indicate strains containing deletions of both the $d d r A$ and $d d r B$ genes

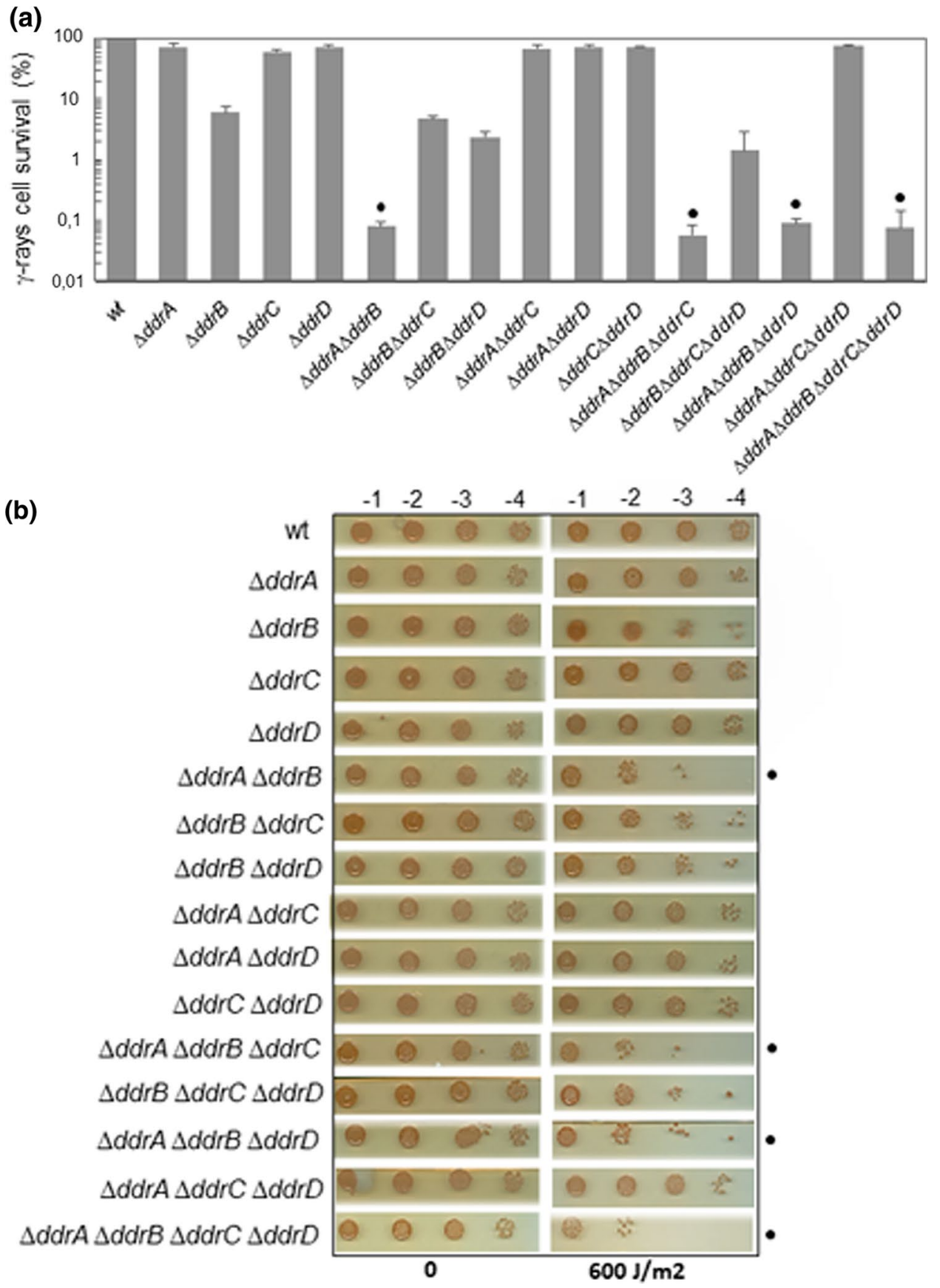

at $750 \mathrm{~J} \mathrm{~m}^{-2}$ and the absence of $d d r C$ in $\Delta u v r A$ and $\Delta u v s E$ mutants increased the UV sensitivity of the resulting double mutants. As UvrA and UvsE proteins belong to the UvrABC dependent nucleotide excision repair and UVDE repair pathways (Moseley and Evans 1983), respectively, it was suggested that DdrC could be involved in DNA repair of highly UVdamaged DNA. However, such a role could not be attributed to DdrD because the $\Delta d d r D$ mutant exhibited a UV sensitivity comparable to that of the wild type strain at $750 \mathrm{~J} \mathrm{~m}^{-2}$ and the $d d r D$ deletion in $\Delta u v r A$ and $\Delta u v s E$ mutants had no effect on the UV sensitivity (Fig. S4). Finally, we tested if the $d d r D$ deletion increased UV sensitivity of a pprA mutant, as previously described (Selvam et al. 2013), but in our hands, the UV sensitivity of the $\triangle p p r A \Delta d d r D$ double mutant was comparable to that of the $\triangle p p r A$ single mutant (Fig. S4), indicating that the activities of PprA and DdrD do not overlap in vivo. 


\section{The absence of the $d d r D$ gene in the $\Delta d d r B$ mutant partially restores the frequency of plasmid transformation}

The $D$. radiodurans bacterium, characterized by its extreme radioresistance, is also naturally competent. In this process, DNA is translocated as ssDNA into the cytosol and protected from degradation by ssDNA binding proteins prior integration into the chromosome by homologous recombination or reconstituted to form an autonomous plasmid (Kruger and Stingl 2011). In bacteria, several ssDNA binding proteins (SSB) as SSB, DprA, RecA, and RecO protect internalized ssDNA from degradation by nucleases (Kidane et al. 2012). The establishment of plasmid DNA requires a single strand annealing to pair internalized complementary plasmid DNA fragments to reconstitute a circular replicon in naturally transformable bacteria such as Streptococcus pneumoniae and Bacillus subtilis (Kidane et al. 2009; Saunders and Guild 1981). In B. subtilis, RecO and DprA mediate annealing of two complementary strands (Yadav et al. 2013) while in D. radiodurans, RecO seems to play a minor role in plasmid transformation when DdrB is present in the cells (Ithurbide et al. 2020). DdrB, through its ability to bind to ssDNA and SSB-like properties, participates in the protection of internalized ssDNA (Ithurbide et al. 2020). It was also previously showed that cells devoid of DdrB were affected in the establishment of plasmid DNA during natural transformation in $D$. radiodurans (de la Tour et al. 2011) suggesting that DdrB likely participates to the plasmid reconstruction through its single strand annealing activity. Here, we tested whether the absence of the $d d r D$ gene would affect the frequency of plasmid transformation in $D$. radiodurans. We observed that the frequency of transformation of plasmid DNA in the $\Delta d d r D$ mutant was the same as in the wild type strain (Fig. 7). However, while the frequency of transformation by plasmid DNA decreased approximately 90-fold in the single $\Delta d d r B$ mutant compared to the wild type strain, it decreased only approximately 18 -fold in the $\Delta d d r B$ $\Delta d d r D$ double mutant. Thus, the absence of DdrD partially restored the frequency of transformation of the $\Delta d d r B$ mutant indicating that some proteins were able to reconstruct the plasmid in the absence of DdrB and DdrD. We suggest that DdrD, through its ability to bind ssDNA, could partially prevent the actors of plasmid transformation such as $\mathrm{RecO}$ or DprA from reconstructing an intact plasmid from ssDNA fragments in the absence of DdrB. The transformation process in a $\Delta d d r B$ $\triangle d d r D$ double mutant would, therefore, be more efficient than in a $\triangle d d r B$ single mutant.

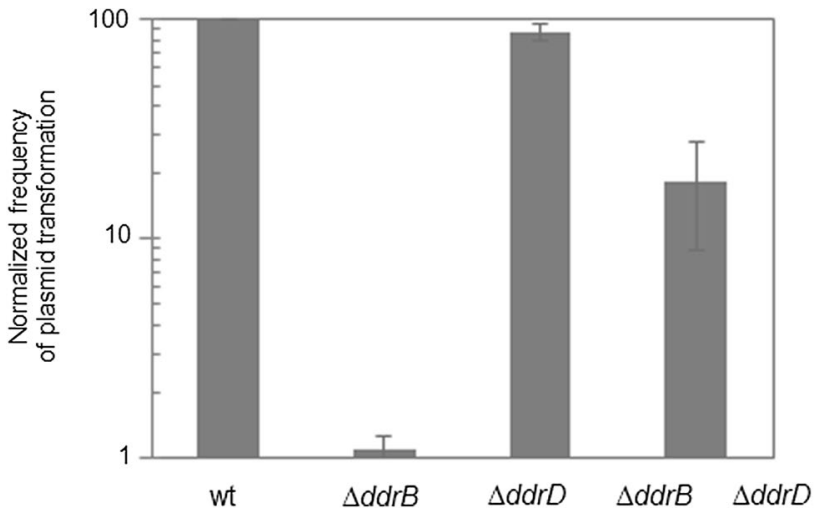

Fig. 7 Frequencies of plasmid transformation in single $\Delta d d r B$, $\Delta d d r D$, and $\Delta d d r B \Delta d d r D$ double mutants. Bacteria were transformed with $200 \mathrm{ng}$ p11559 plasmid (conferring spectinomycin resistance). Transformation frequencies were expressed as the number of $\operatorname{spec}^{R}$ transformants divided by the total number of viable cells in the transformation mixture. The values obtained were normalized relative to that of the wild type strain, taken as 100 . The results are the mean of at least three experiments

\section{Conclusion}

In this study, we showed that DdrD belongs to the family of ssDNA binding proteins including the deinococcal specific Ddr proteins, DdrA, DdrB, DdrC, whose expression is highly induced following $\gamma$-irradiation. The $d d r D$ gene expression is controlled by the IrrE/DdrO protein pair, a very efficient regulation system known in $D$. radiodurans. Although the redundant activities of these Ddr proteins make it difficult to assign a precise role to each of them, we propose that DdrD protein, through its ability to bind to ssDNA as well as to $5^{\prime}$ overhang DNA ends, helps cells to recover from DNA damage when $D$. radiodurans is exposed to an extensive genotoxic stress. Moreover, like other ssDNA binding proteins, DdrD might also regulate efficiency of transformation in this bacterium.

Supplementary Information The online version contains supplementary material available at https://doi.org/10.1007/s00792-021-01233-0.

Acknowledgements We thank Michael M. Cox and J. Timmins for the gift of the purified DdrD and DdrC proteins, respectively. We thank Michael Dubow for polishing our English. We thank also the Institute Curie for the use of the ${ }^{137} \mathrm{Cs}$ irradiation system. This work was carried out in compliance with the current laws governing genetic experimentation in France. This work was supported by the Centre National de la Recherche Scientique and the Université Paris-Saclay.

\section{Declarations}

Conflict of interest The authors declare no conflict of interest. 
Open Access This article is licensed under a Creative Commons Attribution 4.0 International License, which permits use, sharing, adaptation, distribution and reproduction in any medium or format, as long as you give appropriate credit to the original author(s) and the source, provide a link to the Creative Commons licence, and indicate if changes were made. The images or other third party material in this article are included in the article's Creative Commons licence, unless indicated otherwise in a credit line to the material. If material is not included in the article's Creative Commons licence and your intended use is not permitted by statutory regulation or exceeds the permitted use, you will need to obtain permission directly from the copyright holder. To view a copy of this licence, visit http://creativecommons.org/licenses/by/4.0/.

\section{References}

Blanchard L, Guerin P, Roche D, Cruveiller S, Pignol D, Vallenet D, Armengaud J, de Groot A (2017) Conservation and diversity of the IrrE/DdrO-controlled radiation response in radiationresistant Deinococcus bacteria. Microbiologyopen. https://doi. org/10.1002/mbo3.477

de Groot A, Roche D, Fernandez B, Ludanyi M, Cruveiller S, Pignol D, Vallenet D, Armengaud J, Blanchard L (2014) RNA sequencing and proteogenomics reveal the importance of leaderless mRNAs in the radiation-tolerant bacterium Deinococcus deserti. Genome Biol Evol 6:932-948. https://doi.org/10.1093/ gbe/evu069

de la Tour CB, Toueille M, Jolivet E, Nguyen HH, Servant P, Vannier F, Sommer S (2009) The Deinococcus radiodurans SMC protein is dispensable for cell viability yet plays a role in DNA folding. Extremophiles 13:827-837

de la Tour CB, Boisnard S, Norais C, Toueille M, Bentchikou E, Vannier F, Cox MM, Sommer S, Servant P (2011) The deinococcal DdrB protein is involved in an early step of DNA double-strand break repair and in plasmid transformation through its singlestrand annealing activity. DNA Repair (amst) 10:1223-1231. https://doi.org/10.1016/j.dnarep.2011.09.010

de la Tour CB, Passot FM, Toueille M, Mirabella B, Guerin P, Blanchard L, Servant P, de Groot A, Sommer S, Armengaud J (2013) Comparative proteomics reveals key proteins recruited at the nucleoid of Deinococcus after irradiation-induced DNA damage. Proteomics 13:3457-3469. https://doi.org/10.1002/pmic. 201300249

de la Tour CB, Mathieu M, Meyer L, Dupaigne P, Passot F, Servant $\mathrm{P}$, Sommer S, Le Cam E, Confalonieri F (2017) In vivo and in vitro characterization of DdrC, a DNA damage response protein in Deinococcus radiodurans bacterium. PLoS ONE 12:e0177751. https://doi.org/10.1371/journal.pone.0177751

Devigne A, Mersaoui S, de la Tour CB, Sommer S, Servant P (2013) The PprA protein is required for accurate cell division of gammairradiated Deinococcus radiodurans bacteria. DNA Repair (amst) 12:265-272. https://doi.org/10.1016/j.dnarep.2013.01.004

Devigne A, Ithurbide S, de la Tour CB, Passot F, Mathieu M, Sommer $S$, Servant $P$ (2015) DdrO is an essential protein that regulates the radiation desiccation response and the apoptotic-like cell death in the radioresistant Deinococcus radiodurans bacterium. Mol Microbiol 96:1069-1084. https://doi.org/10.1111/mmi.12991

Devigne A, Guerin P, Lisboa J, Quevillon-Cheruel S, Armengaud J, Sommer S, de la Tour CB, Servant P (2016) PprA protein is involved in chromosome segregation via its physical and functional interaction with DNA gyrase in irradiated Deinococcus radiodurans bacteria. $\mathrm{mSphere.} \mathrm{https://doi.org/10.1128/mSphe}$ re.00036-15

Gutsche I, Vujicic-Zagar A, Siebert X, Servant P, Vannier F, Castaing B, Gallet B, Heulin T, de Groot A, Sommer S, Serre L
(2008) Complex oligomeric structure of a truncated form of DdrA: a protein required for the extreme radiotolerance of Deinococcus. Biochim Biophys Acta 1784:1050-1058. https:// doi.org/10.1016/j.bbapap.2008.03.009

Harris DR, Tanaka M, Saveliev SV, Jolivet E, Earl AM, Cox MM, Battista JR (2004) Preserving genome integrity: the DdrA protein of Deinococcus radiodurans R1. PLoS Biol 2:e304. https:// doi.org/10.1371/journal.pbio.0020304

Harris DR, Ngo KV, Cox MM (2008) The stable, functional core of DdrA from Deinococcus radiodurans R1 does not restore radioresistance in vivo. J Bacteriol 190:6475-6482. https://doi. org/10.1128/JB.01165-07

Hua X, Hua Y (2016) Improved complete genome sequence of the extremely radioresistant bacterium Deinococcus radiodurans R1 obtained using pacbio single-molecule sequencing. Genome Announc. https://doi.org/10.1128/genomeA.00886-16

Ishino Y, Narumi I (2015) DNA repair in hyperthermophilic and hyperradioresistant microorganisms. Curr Opin Microbiol 25:103-112. https://doi.org/10.1016/j.mib.2015.05.010

Ithurbide S, Coste G, Lisboa J, Eugenie N, Bentchikou E, de la Tour CB, Liger D, Confalonieri F, Sommer S, Quevillon-Cheruel S, Servant $\mathrm{P}$ (2020) Natural transformation in Deinococcus radiodurans: a genetic analysis reveals the major roles of DprA, DdrB, RecA, RecF, and RecO proteins. Front Microbiol 11:1253. https:// doi.org/10.3389/fmicb.2020.01253

Kidane D, Carrasco B, Manfredi C, Rothmaier K, Ayora S, Tadesse S, Alonso JC, Graumann PL (2009) Evidence for different pathways during horizontal gene transfer in competent Bacillus subtilis cells. PLoS Genet 5:e1000630. https://doi.org/10.1371/journ al.pgen. 1000630

Kidane D, Ayora S, Sweasy JB, Graumann PL, Alonso JC (2012) The cell pole: the site of cross talk between the DNA uptake and genetic recombination machinery. Crit Rev Biochem Mol Biol 47:531-555. https://doi.org/10.3109/10409238.2012.729562

Kota S, Charaka VK, Misra HS (2014a) PprA, a pleiotropic protein for radioresistance, works through DNA gyrase and shows cellular dynamics during postirradiation recovery in Deinococcus radiodurans. J Genet 93:349-354

Kota S, Charaka VK, Ringgaard S, Waldor MK, Misra HS (2014b) PprA contributes to Deinococcus radiodurans resistance to nalidixic acid, genome maintenance after DNA damage and interacts with deinococcal topoisomerases. PLoS ONE 9:e85288. https:// doi.org/10.1371/journal.pone.0085288

Kruger NJ, Stingl K (2011) Two steps away from novelty-principles of bacterial DNA uptake. Mol Microbiol 80:860-867. https://doi. org/10.1111/j.1365-2958.2011.07647.x

Lu H, Chen H, Xu G, Shah AM, Hua Y (2012) DNA binding is essential for PprI function in response to radiation damage in Deinococcus radiodurans. DNA Repair (amst) 11:139-145. https://doi.org/ 10.1016/j.dnarep.2011.10.013

Lusetti SL, Wood EA, Fleming CD, Modica MJ, Korth J, Abbott L, Dwyer DW, Roca AI, Inman RB, Cox MM (2003) C-terminal deletions of the Escherichia coli RecA protein. Characterization of in vivo and in vitro effects. J Biol Chem 278:16372-16380. https://doi.org/10.1074/jbc.M212917200

Makarova KS, Omelchenko MV, Gaidamakova EK, Matrosova VY, Vasilenko A, Zhai M, Lapidus A, Copeland A, Kim E, Land M, Mavrommatis K, Pitluck S, Richardson PM, Detter C, Brettin T, Saunders E, Lai B, Ravel B, Kemner KM, Wolf YI, Sorokin A, Gerasimova AV, Gelfand MS, Fredrickson JK, Koonin EV, Daly MJ (2007) Deinococcus geothermalis: The pool of extreme radiation resistance genes shrinks. PLoS ONE 2:e955

Mennecier S, Coste G, Servant P, Bailone A, Sommer S (2004) Mismatch repair ensures fidelity of replication and recombination in the radioresistant organism Deinococcus radiodurans. Mol Genet Genomics 272:460-469 
Moseley BE, Evans DM (1983) Isolation and properties of strains of Micrococcus (Deinococcus) radiodurans unable to excise ultraviolet light-induced pyrimidine dimers from DNA: evidence for two excision pathways. J Gen Microbiol 129:2437-2445

Narumi I, Satoh K, Cui S, Funayama T, Kitayama S, Watanabe H (2004) PprA: a novel protein from Deinococcus radiodurans that stimulates DNA ligation. Mol Microbiol 54:278-285

Norais CA, Chitteni-Pattu S, Wood EA, Inman RB, Cox MM (2009) DdrB protein, an alternative Deinococcus radiodurans SSB induced by ionizing radiation. J Biol Chem 284:21402-21411

Saunders CW, Guild WR (1981) Pathway of plasmid transformation in Pneumococcus: open circular and linear molecules are active. J Bacteriol 146:517-526. https://doi.org/10.1128/JB.146.2.517526.1981

Selvam K, Duncan JR, Tanaka M, Battista JR (2013) DdrA, DdrD, and PprA: components of UV and mitomycin C resistance in Deinococcus radiodurans R1. PLoS ONE 8:e69007. https://doi.org/10. 1371/journal.pone.0069007

Slade D, Radman M (2011) Oxidative stress resistance in Deinococcus radiodurans. Microbiol Mol Biol Rev 75:133-191. https://doi.org/ 10.1128/MMBR.00015-10

Tanaka M, Earl AM, Howell HA, Park MJ, Eisen JA, Peterson SN, Battista JR (2004) Analysis of Deinococcus radiodurans's transcriptional response to ionizing radiation and desiccation reveals novel proteins that contribute to extreme radioresistance. Genetics 168:21-33

Wang Y, Xu Q, Lu H, Lin L, Wang L, Xu H, Cui X, Zhang H, Li T, Hua Y (2015) Protease activity of PprI facilitates DNA damage response: Mn2+-dependence and substrate sequence-specificity of the proteolytic reaction. PLoS ONE 10:e0122071. https://doi. org/10.1371/journal.pone.0122071

White O, Eisen JA, Heidelberg JF, Hickey EK, Peterson JD, Dodson RJ, Haft DH, Gwinn ML, Nelson WC, Richardson DL, Moffat KS, Qin H, Jiang L, Pamphile W, Crosby M, Shen M, Vamathevan JJ, Lam P, McDonald L, Utterback T, Zalewski C, Makarova KS, Aravind L, Daly MJ, Minton KW, Fleischmann RD, Ketchum KA, Nelson KE, Salzberg S, Smith HO, Venter JC, Fraser CM (1999) Genome sequence of the radioresistant bacterium Deinococcus radiodurans $\mathrm{R} 1$. Science 286:1571-1577

Xu G, Lu H, Wang L, Chen H, Xu Z, Hu Y, Tian B, Hua Y (2010) DdrB stimulates single-stranded DNA annealing and facilitates RecA-independent DNA repair in Deinococcus radiodurans. DNA Repair (amst) 9:805-812

Yadav T, Carrasco B, Hejna J, Suzuki Y, Takeyasu K, Alonso JC (2013) Bacillus subtilis DprA recruits RecA onto single-stranded DNA and mediates annealing of complementary strands coated by SsbB and SsbA. J Biol Chem 288:22437-22450. https://doi.org/10. 1074/jbc.M113.478347

Zheng X, Hu GQ, She ZS, Zhu H (2011) Leaderless genes in bacteria: clue to the evolution of translation initiation mechanisms in prokaryotes. BMC Genomics 12:361. https://doi.org/10.1186/ 1471-2164-12-361

Publisher's Note Springer Nature remains neutral with regard to jurisdictional claims in published maps and institutional affiliations. 